\title{
HUMAN INTERACTION WITH CARIBBEAN KARST LANDSCAPES: PAST, PRESENT AND FUTURE
}

\section{VPLIV ČLOVEKA NA KRAŠKO POKRAJINO NA KARIBIH: PRETEKLOST, SEDANJOST IN PRIHODNOST}

\author{
Mick DAY ${ }^{1}$
}

\begin{abstract}
UDC 551.44(729)

Mick Day: Human Interaction with Caribbean Karst Landscapes: Past, Present and Future

Karst provides a critical physical backdrop for much of the Caribbean's history and many of its existing environmental, agricultural, economic and cultural issues. The karstlands are challenging to human habitation, since they possess a broad array of natural hazards, but they are also at risk of degradation and vulnerable to environmental change. The karst has a rich legacy of pre-Colombian settlement and contains many regional archaeological sites. Unsustainable European colonial agricultural practices degraded the vegetation and landscape severely. The karstlands also played a major role in resistance to colonial authority, and were used by Maroons as both refuges and bases for harassment and guerilla actions. Following emancipation and independence, the karst became a basis for subsistence agriculture, increasingly yielding to commercial agriculture, urbanization and industrial activities, and tourism. Despite hazards such as drought and flooding, human impacts on the karstlands have been long-term and severe. Regional predictions are that anthropogenic climatic change will lead to rising sea levels, changing precipitation totals and the increasing frequency of extreme events, such as droughts and hurricanes. The effects of all these changes will be magnified in the karst, particularly with respect to karst hydrology. Climate change and other human impacts will increasingly threaten already at-risk and vulnerable ecosystems and human communities, necessitating integration of climate change parameters and the adoption of appropriate risk management measures.
\end{abstract}

Keywords: Caribbean, karst, history, hazards, climate change, management.
Izvleček

UDK 551.44(729)

Mick Day: Vpliv človeka na kraško pokrajino na Karibih: preteklost, sedanjost in prihodnost

Kras je močno povezan $\mathrm{z}$ zgodovino ter okoljsko, gospodarsko, kmetijsko in kulturno problematiko Karibov. Kraška območja predstavljajo številne izzive pri upravljanju $\mathrm{z}$ naravo. Po eni strani so na krasu povečana tveganja za naravne nesreče, po drugi strani pa je kraška pokrajina posebej občutljiva za degradacijo in okoljske spremembe. $\mathrm{Na}$ krasu najdemo veliko arheoloških najdišč predkolumbskih kultur. Evropsko kolonialno kmetijstvo, ki seveda ni bilo sonaravno, je povzročilo veliko škode na vegetaciji in kraškem površju. Kraška območja so bila pomembna pri uporih proti kolonialni oblasti. Specifiko kraške pokrajine so za skrivanje in gverilske akcije izkoriščali Marooni. Po osamosvajanju so kraška območja postala pomembna za kmetijstvo, urbanizacijo in turizem. Kljub tveganjem suše in poplav, je vpliv človeka na kras dolgoročen. Po napovedih naj bi klimatkse spremembe $\mathrm{v}$ regiji povzročile naraščanje morske gladine, spremembe $\mathrm{v}$ količini padavin in večjo pogostost izjemnih vremenskih dogodkov, kot so suše in orkani. Učinki teh dogodkov bodo na krasu še močneje izraženi, posebej z ozirom na kraško hidrologijo. Klimatkse spremembe in človekov vpliv bo vse bolj ogrožal že tako ogrožene kraške ekosisteme in skupnosti prebivalcev na Karibih. Vse grožeče spremembe bo protrebno vnesti v načrte upravljanja območja.

Ključne besede: Karibi, kras, zgodovina, naravne nesreče, klimatske spremembe, upravljanje.

\footnotetext{
${ }^{1}$ Department of Geography, University of Wisconsin-Milwaukee, 3210 North Maryland Avenue, Milwaukee, WI 53201, USA, e-mail: mickday@uwm.edu
}

Received/Prejeto: 4.9.2007 


\section{INTRODUCTION}

Karst is one of the two landscape types, the other being volcanic terrain, that dominate the Caribbean islands. As such, karst provides a critical physical backdrop for much of the region's history and many of its existing environmental, agricultural, economic and cultural issues. The karst also represents an important 'barometer', indicative of the actual and potential impacts of anthropogenic environmental change.

The Caribbean, defined broadly here as all the islands of the Greater and Lesser Antilles, the Bahamas, Trinidad, Tobago, and the islands of the Netherlands Antilles, and broadly corresponding to the West Indies (Watts 1987), is one of the premier karst regions in the world, with a limestone area of nearly $130,000 \mathrm{~km}^{2}$, more than half the total land area of the region (Day 1993a; Tarhule-Lips 2004). Approximately $90 \%$ of the karst is on the Greater Antilles (Cuba, Hispaniola, Jamaica and
Puerto Rico), with other significant areas in the Bahamas, Anguilla, Antigua, the Cayman Islands, the Virgin Islands, Guadeloupe, Barbados, Trinidad and Tobago and the Netherlands Antilles (Fig. 1). The karstlands are challenging to human habitation, since they possess a broad array of natural hazards, but they are also inherently fragile and vulnerable to environmental change (Day 1993a). The IUCN World Commission on Protected Areas (WCPA) has recognized karst landscapes, including those in the Caribbean, as being at risk of degradation and warranting protection (Watson et al. 1997). An assessment of protected karst areas in the Caribbean region has been initiated (Kueny \& Day 1998), and a series of country-wide studies of karst landuse and conservation is being undertaken (Day 1993b, 1996, 2003b, 2006, 2007a, b; Day \& Chenoweth 2004a; Mujica-Ortiz \& Day 2001).

\section{THE CARIBBEAN KARSTLANDS}

The karstlands of the humid tropics are among the most spectacular anywhere in the world because high temperatures favor chemical erosion, high humidities and rainfall provide abundant water for dissolution, and the environmental conditions encourage high levels of biological activity (Day 2000; Ford \& Williams 2007). The most diagnostic elements of the karst are large more-orless enclosed depressions (dolines or sinkholes; Fig. 2) and systems of dry valleys (Fig. 3). Bordering these negative topographic features are sinuous ridges and interconnected or isolated residual hills, generally known as cones where they are connected (Fig. 4) or as towers where they are isolated by alluvial or other infills in poljes or around the karst peripheries (Fig. 5). Relative relief may exceed $100 \mathrm{~m}$, slopes may be near-vertical, surface collapses may occur, and the ground surface is often unstable or treacherously pitted, with jagged indentations and protrusions (karren). Surface drainage is uncommon with peripheral sinking streams and springs but, perversely, flash floods may occur during intense rainstorms. Large and extensive cave systems are integral to many Caribbean karst areas. The largest karst areas in the Caribbean are on the islands of the Greater Antilles (Cuba, Hispaniola, Jamaica and Puerto Rico) with a total karst area of approximately $115,000 \mathrm{~km}^{2}$. The islands of the Bahamas, the Lesser Antilles, Trinidad, Tobago and the Netherlands Antilles contain an additional 13,000 km2 of karst (Day 1993a, Fig. 1).
The Caribbean karstlands are far from homogeneous with respect to geologic and geomorphic factors. Moreover, climate, soils and biota are also highly variable, leading to a wide range of specific karst environments. The karst rocks themselves range from pure, dense, hard, fractured, crystalline limestones, some much altered from their original state, to impure, powdery, soft, porous, amorphous carbonates. Some are covered by volcanic ash and others have been folded and faulted by tectonic forces. Karst landscape elevations range from below sea level up to 3,000 m; some are mountainous, others planar; some are hydrologically isolated, others receive surface drainage from higher, adjacent non-karst terrains.

Climate varies too, with mean annual precipitation ranging from less than 1,000 to over $3,000 \mathrm{~mm}$. Rainfall generally increases with elevation, and leeward locations experience higher temperatures and lower precipitation than karst areas to the windward. There are distinct winter dry periods of differing onset, intensity and duration and brief midsummer droughts. Summer convection storms result in spatially uneven rainfall distribution. Late summer hurricanes and tropical depressions can cause severe flooding in normally dry karst areas, particularly in valleys and depressions.

Karst soils are also extremely variable, but generally tend to be clay-rich, heavily leached, patchy and thin. Steep slopes tend to be devoid of soils, which are thicker in depression and valley bases, where they are often asso- 


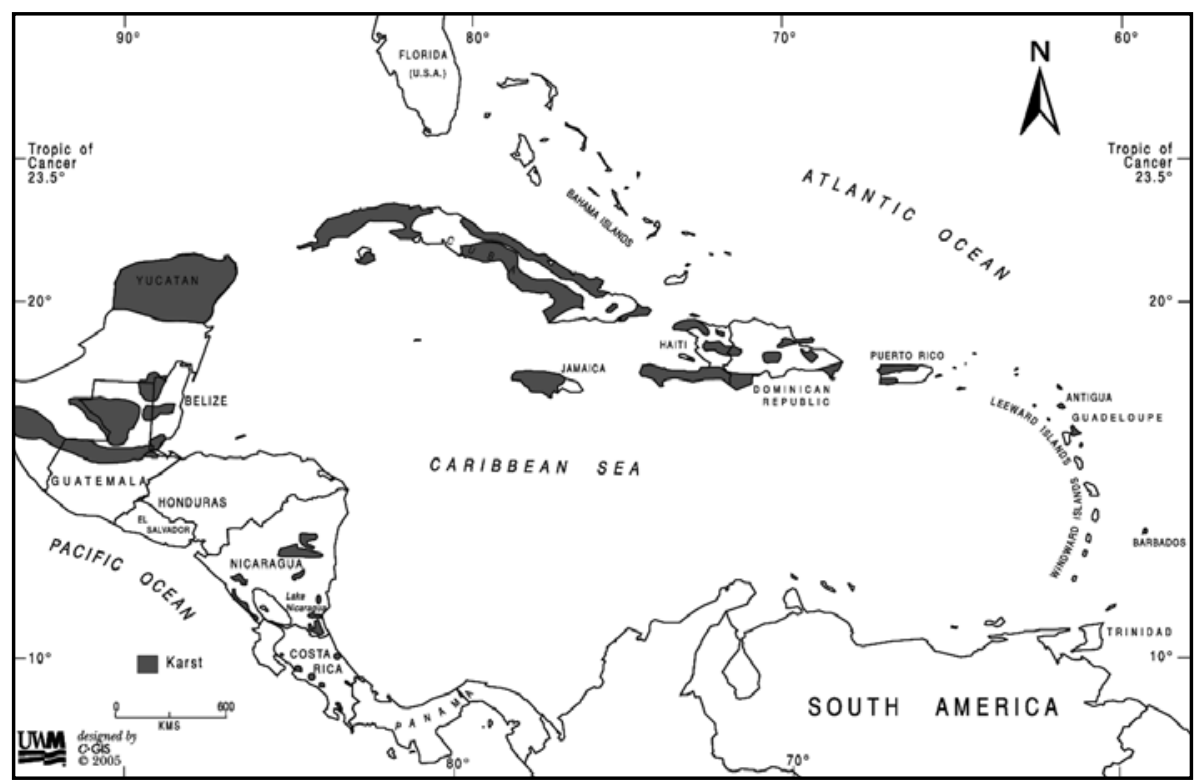

Fig. 1: The Caribbean Karstlands.

ciated with bauxitic infills. Vegetation varies from xerophytic scrub to wet tropical broadleaf forest, with many species endemic to specific islands.

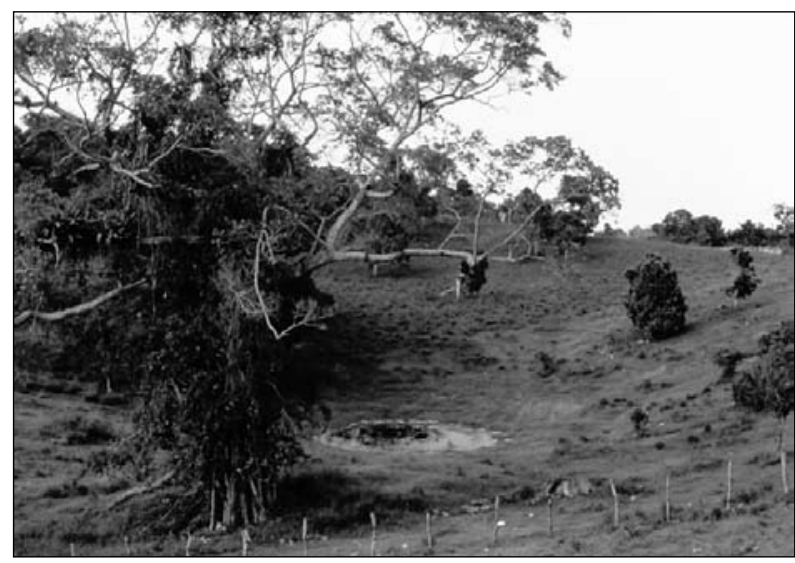

Fig. 2: Doline, Jamaica (Photo: M. Day).

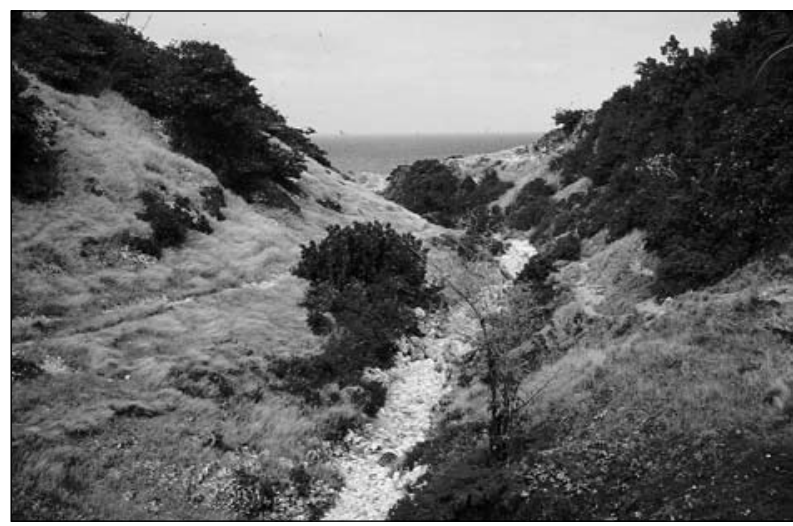

Fig. 3: Dry valley, Barbados (Photo: M. Day).
The Caribbean karst has played a significant role in the history and development of karst science, as the scene of classic studies of cone and tower karst (Lehmann 1954; Sweeting 1958; Panos \& Stelcl 1968), dry valleys (Lasserre 1954; Fermor 1972) and caves (Brown \& Ford 1973).

Other studies have emphasized the variability of the Caribbean carbonate sequences, and how this has influenced karst development (e.g., Nunez Jimenez 1984; Monroe 1976). Perhaps most significantly, the Caribbean islands, in particular the Bahamas, nurtured the development of the Carbonate Island Karst Model (CIKM), which recognizes that eogenic island karst development is distinct from karst development in larger islands or continental settings (Mylroie 2004; Mylroie \& Carew 1990, 1995, 2000).

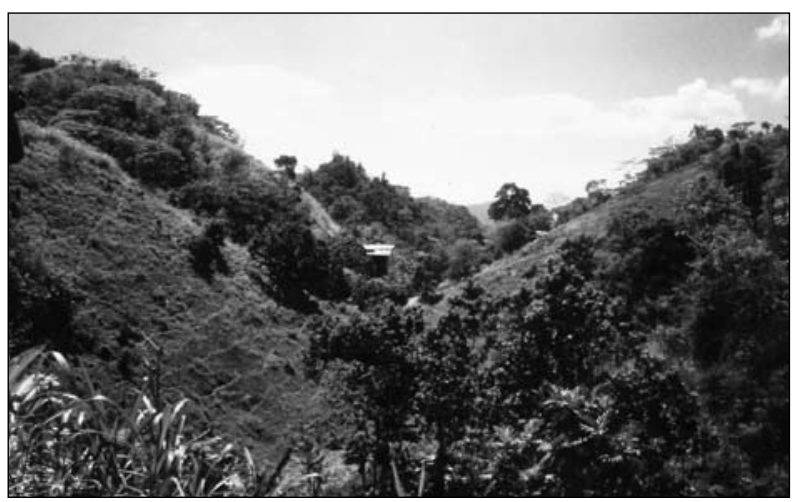

Fig. 4: Cone karst, Trinidad (Photo: M. Day).

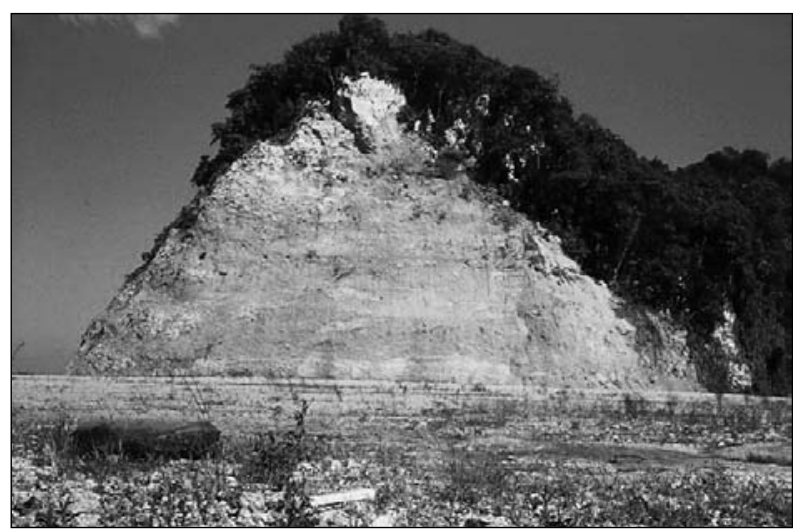

Fig. 5: Tower karst, Puerto Rico (Photo: M. Day). 


\section{CARIBBEAN KARST IN HISTORY}

The karst has provided the backdrop for human activities since the Caribbean was first peopled, and karst areas throughout the region have a rich legacy of pre-Colombian settlement (Rouse 1992; Wilson 2007). The karst was an important regional source of flint or chert for fabrication of stone tools (e.g., Davis 1993), and many regional archaeological sites are within the karst. Native inhabitants had profound influences on the natural vegetation, using native species and introducing others (Harris 1965; Watts 1987). Many species represented as fossils are either extinct or have never been recorded historically, suggesting extinction as a result of human-caused environmental degradation (e.g., Steadman et al. 1984).

European colonial agriculture in the karst was dominated by the production of sugar cane, cotton and tobacco in the less rugged and more easily accessible areas. The primary impact on the karst was the clearance of natural vegetation; in many areas the intensity of sugar monoculture and the associated unsustainable agricultural practices degraded the vegetation and landscape severely (Watts 1987; Thompson 2002; Besson \& Momsen 2007).

The karstlands also played a major role in resistance to colonial authority, and were used by Maroons as both refuges and bases for harassment and guerilla actions (Thompson 2006). The karst in Jamaica and Hispaniola was particularly significant in this respect, but karst terrain also provided a sanctuary for Maroons in Puerto Rico, Barbados, Antigua, Grand Terre, Guadeloupe and the Virgin Islands (Donoghue 2002; Handler 2003). The karstlands posed unusual military problems for the colonists. The irregular topography, restricted surface water supply, and the suitability of caves for refuge and ambush, afforded strategic offensive and defensive advantages to Maroons familiar with the surface and underground terrain, and posed tactical problems for foreign forces (Day \& Kueny 2004).

Perhaps the most effective Maroon campaigns based on the karst were those which took place in Jamaica's Cockpit Country during the Maroon Wars between 1690 and 1796 (Eyre 1980; Day 2004). The Cockpit Country is the spectacular "type example" of what Ford and Williams (2007) describe as the "egg-box" style of karst terrain, and is centered on Trelawny Parish, covering about $600 \mathrm{~km} 2$. The cockpits are steep-sided, moreor-less enclosed lobate depressions, some over $100 \mathrm{~m}$ deep and $1 \mathrm{~km}$ in diameter, and so named because they resemble the arenas formerly used for cock fighting (Day \& Chenoweth 2004b).

The Maroon Wars encompassed a protracted series of variously energetic military engagements between co- lonial forces and the Maroons, who adopted hit-and-run guerrilla tactics. The Maroon Wars were the only significant British colonial conflict conducted in humid tropical forests before World War II, and the inexperienced troops' adversaries were the terrain and the climate as much as the Maroons themselves (Eyre 1980; Day 2004). They found the unaccustomed terrain confusing and difficult to traverse, becoming disoriented and injured, without adequate water supplies. By contrast, the Maroons made tactical advantage of their intimacy with the terrain, utilizing refuges in the least accessible reaches, but maintaining access to the few water sources. They selected ambush locations in which the British were confined to single file, particularly within narrow rocky corridors, and from which the Maroons themselves could make speedy egress into the maze of cockpits, hills and caves.

During the First Maroon War (1730 to 1739) the Maroons established their Cockpit Country base in Pettee River Bottom, a particularly defensible although rather atypical karst depression near the western margin of the Cockpit Country. The Bottom has a perennial water source, is flanked by rugged ridges and hills, which provide convenient lookout points, and is accessible only via narrow corridors at the southern and northwestern ends. The Maroons used these narrow corridors to ambush and halt advancing British troops (Eyre 1980). Infantry efforts to penetrate the Maroons' stronghold were repeatedly repelled, with mounting losses, and the British negotiated an uneasy truce.

The cessation of hostilities lasted over fifty years, with intermittent interruptions, until 1795, when the yearlong Second Maroon War broke out. This time the British deployed both infantry and cavalry forces against the Maroons, again ensconced in their Cockpit Country bastion. The initial results were the same - Pettee River Bottom proved impregnable, and the British incurred mounting losses. Admitting that conventional confrontation and pursuit were ineffectual in the Cockpit Country, the launched an artillery bombardment upon the Pettee River Bottom from an adjacent hilltop, which is still known as Gun Hill, whence the Maroons were steadily shelled until they withdrew deeper into the interior of the Cockpit Country.

Having thus been displaced from their primary water supply, the Maroons became increasingly dependent on the intermittent rainfall and upon the few ephemeral water sources in the Cockpit Country interior with which they were less familiar. The British further weakened the Maroon situation by encircling the Cockpit Country with a road network, stationing troops at strategic points and 
restricting access to the peripheral springs. A campaign of attrition set in, with the British entrenched around the periphery and the Maroons continuing to harass them, until hostilities ended with signing of the Pond River Treaty of 1796.

\section{THE CONTEMPORARY CARIBBEAN KARST}

Following emancipation and independence, the Caribbean karst became a basis for subsistence agriculture, increasingly yielding to commercial agriculture, urbanization and industrial activities, and tourism (Watts 1987; Thompson 2002; Besson \& Momsen 2007). Beyond the overall roughness of much of the terrain, which makes access and construction challenging in general, the major problem in the karst is drought and water supply. Shortterm dry season drought is a recurrent problem, but may also extend over longer periods and become severe, leading to crop and livestock losses, bush fires, and emergency distribution of water supplies (Lashley \& Bandara 2001). Although considerable progress has been made throughout the karst in the provision of reliable urban water supplies via wells and pumps, much of the rural water supply still relies in large part upon collection of rainwater in tanks from roofs and gutters (Fig. 6). These collection systems, although simple and environmentally-friendly, have their limitations. Storage capacity is limited, and supply is unreliable, being characterized by periods of deficit or surplus. Storage may be further compromised by evaporation and leakage, or by accidental contamination, and the water may be deficient in minerals such as calcium, which would otherwise be dissolved during percolation.

Springs remain the other important source of rural water supply, particularly around the karst peripheries. Major perennial springs are the most reliable, but some communities also utilize seasonal and ephemeral springs when discharge is adequate. Drought conditions often require authorities or individuals to bring in water by trucks from non-karst areas or from remaining sources within the karst itself.

Conversely, and perversely, flooding actually poses a greater hazard than drought and has more serious short-term consequences, including human death, injury and displacement, and damage to homes and other structures (O'Hara 1990; Lashley \& Bandara 2001). Flooding of karst landscapes is an integral component of the natural karst hydrology, although it remains problematic to predict. Flooding within the karst occurs through a number of distinct, but often complementary mechanisms, and affects only certain parts of the landscape (Day 1979, 2007a).
Occasional collapse and subsidence also occur, although the Caribbean has not yet suffered their effects as catastrophically as elsewhere (Waltham et al. 2005). Certain sites, such as lower slopes and depression bases, are especially prone to collapse, but only about $10-15 \%$ of sites show any evidence of collapse or subsidence, suggesting that collapse probabilities are generally low (Day 1984, 2003a). Despite these relatively low probabilities, both ground surface collapse and subsidence represent an increasing threat to developing infrastructure, such as highways and public service facilities, plus a minor hazard to rural dwellings and livestock. Slope failure also poses a minor to moderate hazard to buildings, roads and other structures, although one that is rarely recognized (Day 1978).

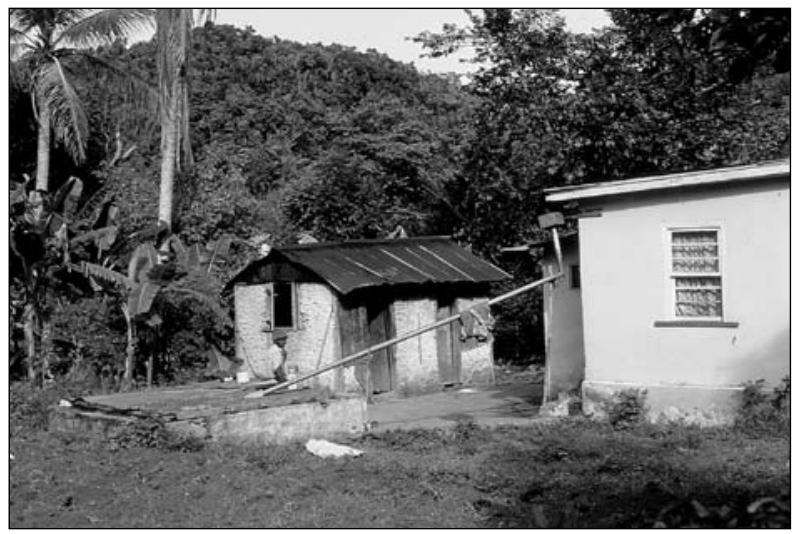

Fig. 6: Rainwater collection, Belize (Photo: M. Day).

These difficulties notwithstanding, colonial and later impacts on the karstlands have been long-term and severe (Day 1993a), in particular through forest clearing, species introduction, agriculture, utilization of water resources, urbanization and industrial activities and tourism. With a karst area of nearly $130,000 \mathrm{~km} 2$ and a population of perhaps 15 million people, pressures on the karstlands are already heavy, and increasing populations and economic development are exacerbating impacts, in particular through clearing of remaining natural vegetation, species extinction or introduction, expanding agriculture, increasing utilization and contamination of water resources, tourism, urbanization and industrial activities, including quarrying and mining. 
Forest clearance and agriculture have had profound and long-term effects on the karst landscape. Much of the karst is utilized for some form of agriculture, and these activities are increasing steadily. Loss of native vegetation and declining habitat apart, some Caribbean karst area soils have been degraded, and their physical and chemical characteristics modified by plowing, cultivation, drainage modification and use of chemicals (Fig. 7). Sediment eroded from agricultural lands frequently has blocked sinkholes and other karst drainage features, and flooding has been exacerbated locally by infilling of sinks and depressions.

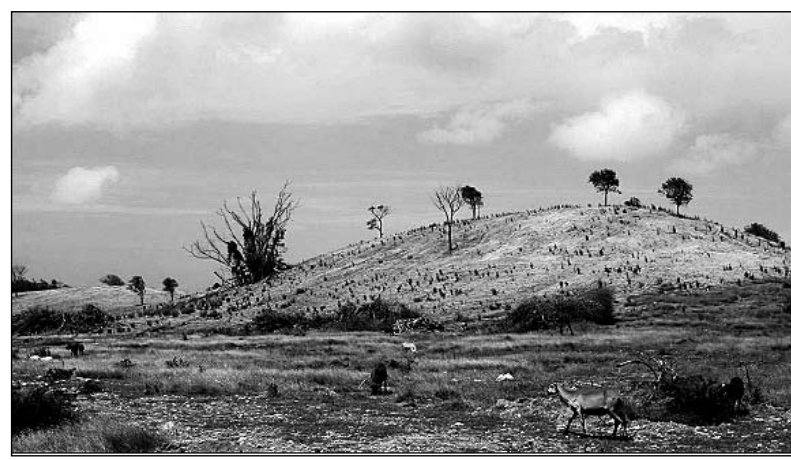

Fig. 7: Soil degradation, Antigua (Photo: M. Day).

Limestone quarrying for roadbed and general construction has had an impact both locally and nationally, but the most significant quarrying has been for cement production. Regionally, the annual production of limestone in 2004 was about $16 \mathrm{~m} \mathrm{Mt}$, and cement production was nearly $8.5 \mathrm{~m} \mathrm{Mt} \mathrm{(USGS} \mathrm{2006).} \mathrm{Lime} \mathrm{production}$ was over 465,000 Mt in 2004 (USGS 2006). There is also a limited amount of marble, gypsum and aragonite mining, and significant petroleum reserves are associated with karst in Cuba, Trinidad, Aruba and Barbados.

Commercial bauxite production began in the $\mathrm{Ca}$ ribbean in the 1950s. Jamaica is the World's third largest bauxite producer, and some 100,000 ha of northern Jamaican karst, particularly in the Dry Harbour Mountains, have been exploited for bauxite and alumina by surface mining, with similar areas affected in the southcentral karst (Fig. 8). By 2004, bauxite and alumina production amounted to $13.3 \mathrm{~m} \mathrm{Mt}$ and $4.08 \mathrm{~m} \mathrm{Mt} \mathrm{respec-}$ tively (USGS 2006). Beyond the physical devastation of the surface karst landscape by bauxite mining, the operations have caused deforestation, ecological damage, air pollution and the displacement of thousands of local residents, particularly from St. Ann Parish.

Ground and surface water contamination is also a serious hazard, particularly where industrial effluents and urban runoff enter underground drainage systems via point recharge. Groundwater contamination has been documented throughout the Caribbean karst where urban and industrial effluents enter the underground flow system. One particular problem has been the contamination of surface waters and groundwater by "red mud", the caustic waste from alumina production (Bell 1986).

Much of the Caribbean karst remains in rural land uses, but urbanization is increasing, particularly in the vicinity of large cities such as San Juan, Port of Spain, Montego Bay, St Johns and Bridgetown. Urban development places increasing demands on the karst for construction materials, and changes irrevocably the inherent structure of the karst land surface, its landforms and hydrology. Large urban areas also exacerbate demands on karst groundwater resources.

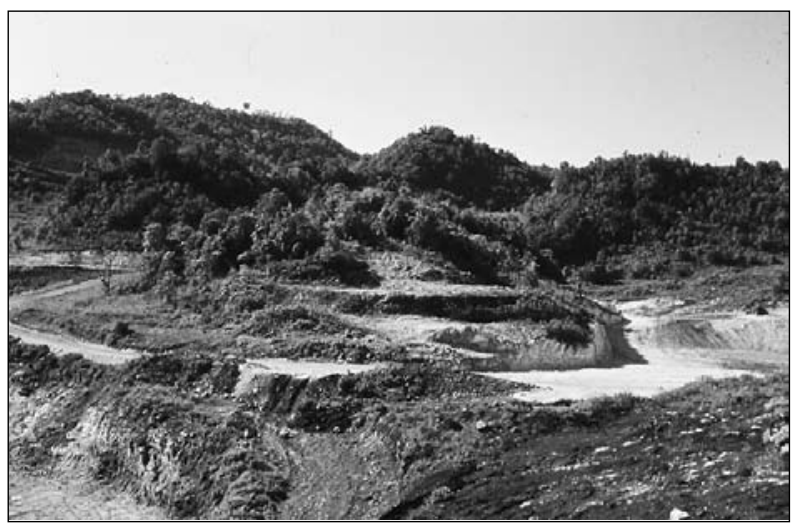

Fig. 8: Bauxite mining, Jamaica (Photo: M. Day).

Another burgeoning human activity in the Caribbean's karst landscapes is tourism, both the traditional form associated with beaches and relaxation, and newer forms of ecotourism and adventure tourism, associated with protected areas, natural landscapes, wildlife, archaeological sites, rivers, cliffs and caves. Tourism in the karst began in the 1950s and boomed in the 1970s and 1980s, now dominating the national economies of many islands and accounting for increasing percentages of GDP, foreign exchange earnings and the labor force. Although it is difficult to quantify exactly to what extent tourism is focused on the karst areas, tourism and its attendant infrastructure have had major impacts, particularly through increasing demands for water and construction materials, and through degradation of water quality (Pattulo 1996). For example, visitors typically use far more water than residents, and hotel activities, such as the discharge of wastewater and application of pesticides and fertilizers to lawns and gardens cause water contamination. Hotel, marina and road construction have altered karst ecosystems, reduced biodiversity, disturbed archaeological sites, caused flooding and beach erosion, and damaged historic artifacts. Locally, tourismrelated pressures may be severe; for example, in Antigua 
the international airport, the main desalinization plants, a major marina, golf courses and about a third of hotels are all located within the karst belt (Day 2007b).

Karst is beginning to be recognized as a significant component of Caribbean ecotourism, particularly in those karst landscapes which remain relatively unaltered by human activities, such as the Cockpit Country of Jamaica (Day 2006). Deep sinkholes, towering residual hills, cliffs, springs and caves are all potential ecotourism foci, particularly in association with intact vegetation and wildlife communities. Investment in ecotourism has, however, been limited by economic and labor constraints, and the sector also remains vulnerable to environmental degradation. It is particularly difficult for the smaller karst-based islands to reconcile the conflicting demands of development and conservation, but larger islands have greater opportunities to benefit sustainably from investment in protected areas and restricted, smallscale tourism development (Duval 2004).

\section{ENVIRONMENTAL CHANGE AND THE CARIBBEAN KARST}

Global scenarios of anthropogenic climate change resulting primarily from Greenhouse Effect warming have been presented by the Intergovernmental Panel on Climate Change (IPCC 2007). Regionally, predictions for the Caribbean in the $21^{\text {st }}$ Century are that anthropogenic climatic change will lead to higher atmospheric carbon dioxide contents, increasing air and water temperatures, rising sea levels and changing weather patterns, including decreasing precipitation totals, and the increasing frequency of extreme events, such as droughts and hurricanes. The effects of all these changes will be magnified in the karst.

In the karst, the most damaging results of climate change will be those arising from changes in the karst hydrology as a result of more frequent dry season droughts and wet season floods. Overall, the impact will be to exacerbate and magnify the existing situation, with increasing frequency of high magnitude events and greater extremes of drought and flooding. Climate change may alter the balance of chemical and mechanical processes and will lead to increases in surface runoff, decreases in surface and underground water storage, decreased spring discharge, and increased sedimentation with karst catchments and caves.

Water resources are already limiting, and disruption of the karst hydrological cycle may lead to increasing aridity and desertification, with concomitant impacts on ecology and potential land use, similar to that experienced already in southern China (Yuan 1997). Increasing drought will further limit human access to rainwater and will also result in a diminution of recharge to the groundwater, placing an increased burden upon water resources in general (daCunha 1989). In addition, floodwaters may contribute relatively little to groundwater resources, as well as potentially increasing contaminant loads. The availability of water resources will become increasingly critical in the karst, where water already is in short supply and reliant upon rainwater from small catchments or limited freshwater lenses. Rising sea levels will also increase the risks of saline water intrusion into the restricted fresh water lenses, especially in smaller islands such as Antigua and Barbados, where increasing groundwater salinity is already problematic.

The other major impact of projected climate change will be an increase in flooding within the karstlands. Floods will increasingly produce more serious short-term consequences, including human death, injury and displacement, and damage to homes and other structures. Flooding may still be expected on a similar seasonal or intermittent basis, but it will remain problematic to predict its geographical distribution accurately. Flooding will continue via distinct, but often complementary mechanisms, and will affect increased areas of the karst landscape.

\section{POTENTIAL RESPONSES TO ENVIRONMENTAL CHANGE AND POPULATION PRESSURE}

Environmental change and that brought about more directly by human land use and land cover modifications within the Caribbean karst must be understood in tandem (Dale 1997) and responses must be integrated
(UNEP 2005; Simms \& Reid 2006). Climate change will have environmental impacts at a variety of spatial and temporal scales, but more direct human impacts will override these in many instances. For example, climate 
change may produce changes in soil $\mathrm{CO}_{2}$ levels, but these are also affected by human activities, such as burning (Day 1999). Climate change and other human impacts on the Caribbean karst will result in already at-risk and vulnerable ecosystems and human communities experiencing even greater threats. Combinations of vulnerabilities relating to factors such as resource availability and poverty will render certain communities and groups particularly at risk, necessitating integration of climate change parameters and the adoption of appropriate risk management measures (Challenger 2002).

Initially, there is an urgent need for comprehensive regional, national and local surveys of existing conditions and hazards within the Caribbean karst. Recognition of the inherent characteristics of the karst needs to be at the forefront of such surveys, and the region's karstlands need to be clearly identified and delimited. There is a particularly urgent need for increased awareness of the karst area drought hazard and, even more so, of the flooding hazard, especially in known hazard locations. Scale issues also warrant attention, since impacts and responses will occur at a variety of spatial and temporal scales. Proactive steps are required from regional bodies and national governments, but local community actions may ultimately prove more important within the karst.

Once the contemporary situation is understood, then strategies for mitigating future environmental change can be developed rationally and with specific reference to the karst. Strategies directed towards human wellbeing within the karst may include the development and implementation of comprehensive disaster management programs and changes in land use policies. Changing public health risks may be addressed through improved sanitation and health care infrastructure, emergency plans, and public education about the health risks posed by floods and droughts.
Provision of adequate water resources within the karstlands will involve measures such as improved rainfall retention, improved storage and distribution systems, development of alternative water sources, better management of supply and infrastructure, increased conservation, and application of improved technology, including desalinization. Agricultural strategies may include growing more drought-resistant crops, and increased attention to maintenance of soil and water resources. The potential effects of climate change and anthropogenic pressures also need to be integrated into broader community planning and into tourism development.

In a broad sense, the severity of both climatic and other anthropogenic impacts within the karst can best be reduced by appropriate land management and sustainable land use planning, including the expansion and maintenance of protected areas (Kueny \& Day 1998; Day \& Kueny 2006). All elements of natural and humanmodified ecosystems within the karst need to be taken into account. Increased monitoring is required (Day \& Koenig 2002), and priority should be allocated to the maintenance and protection of natural "buffers" within the karst, such as natural vegetation, surface watersheds, caves and groundwater aquifers.

Although most Caribbean nations now recognize the importance of resource protection for environmental, economic and social reasons, the ramifications of climate change and other human impacts increasingly require this to be a priority, particularly within the region's karstlands, where the potential risks to nature and human wellbeing are magnified and accentuated. Changing environmental conditions within the Caribbean karst may well be a portent for the overall environmental health of the region, and the karst thus represents a potential barometer of human ability to respond to the very real threats to environmental sustainability.

\section{ACKNOWLEDGEMENTS}

Research on Caribbean karst has been supported by grants from the University of Wisconsin-Milwaukee's Center for Latin American and Caribbean Studies.

\section{REFERENCES}

Bell, J., 1986: Caustic waste menaces Jamaica.- New Scientist, 3, 1502, 33-37.
Besson, J. \& J.H. Momsen, 2007: Caribbean Land and Development Revisited.- Palgrave Macmillan, pp. 228, New York. 
Brown, M.C. \& D.C. Ford, 1973: Caves and groundwater patterns in a tropical karst environment: Jamaica, West Indies.- American Journal of Science, 273, 622-633.

Challenger, B., 2002: Linking Adaptation to Climate Change and Disaster Mitigation in the Eastern Caribbean: Experiences and Opportunities.- [Online] Available from http://www.onu.org.cu/ havanarisk/ papers_cchange3/Challenger.pdf [Accessed 8 February 2007].

daCunha, L.V., 1989: Climate change and water resources development.- In: Berger, A., Schneider, S. \& J.C. Duplessy, (eds.) Climate and Geosciences. NATO ASI Series C: Mathematical and Physical Sciences, 285, Kluwer, pp. 639-660, Dordecht.

Dale, V.H., 1997: The relationship between land-use change and climate change.- Ecological Applications, 7, 3, 753-769.

Davis D.O., 1993: Archaic Blade Production on Antigua, West Indies.- American Antiquity, 58, 4, 688-697.

Day, M.J., 1978: Engineering hazards in tropical karst terrain.- Applied Geography Conferences, 1, 288-298.

Day, M.J., 1979: The hydrology of polygonal karst depressions in northern Jamaica.- Zeitschrift fur Geomorphologie N.F., Supplementbande, 32, 25-34.

Day, M.J., 1984: Predicting the location of surface collapse within karst depressions: A Jamaican example.- In: Beck, B.F. (ed.) Sinkholes: Their Geology, Engineering and Environmental Impact. A.A. Balkema, pp. 147-152, Rotterdam.

Day, M. J., 1993a: Human Impacts on Caribbean and Central American Karst.- In: Williams, P.W. (ed.) Karst Terrains: Environmental Changes and $\mathrm{Hu}-$ man Impact. Catena Supplement 25, pp. 109-125, Cremlingen-Dested.

Day, M.J., 1993b: Resource use in the tropical karstlands of central Belize.- Environmental Geology, 21, 3, 122-128.

Day, M.J., 1996: Conservation of karst in Belize.- Journal of Cave and Karst Studies, 58, 2, 139-144.

Day, M.J., 1999: Short-term decline in soil carbon dioxide concentrations upon burning of secondary vegetation in the karst of Belize.- In: Barany-Kevei, I. \& J. Gunn (eds.) Essays in the Ecology and Conservation of Karst. IGU Commission on Sustainable Development and Management of Karst Terrains, Acta Geographica, 36, 63-69.

Day, M.J., 2000: Tropical karst.- In: Hancock, P.L. \& B.J. Skinner (eds.) The Oxford Companion to the Earth. Oxford University Press, pp.1057-1058, Oxford.

Day, M.J., 2003a: An assessment of karstic collapse hazards at Mount Rosser, Ewarton, Jamaica.- In: Beck, B.F. (ed.) Sinkholes and the Engineering and Envi- ronmental Impacts of Karst. American Society of Civil Engineers, Geotechnical Special Publication, 122, pp. 40-49, Reston, Virginia.

Day, M.J., 2003b: Some observations on karst landscape ecology and conservation in Belize.- Journal of Belizean Affairs, 5, 1, 31-45.

Day, M.J., 2004: Military campaigns in tropical karst terrain: the Maroon Wars of Jamaica.- In: Caldwell, D.R., Ehlen, J. \& R.S. Harmon (eds.) Studies in Military Geography and Geology. Kluwer, pp. 79-88, Dordecht.

Day, M.J., 2006: Stakeholder reaction to the proposed establishment of the National Park, Cockpit Country, Jamaica.- In: Simonic, P. (ed.) Ethnography of Protected Areas: Endangered Habitats - Endangered Cultures. Filozofska fakulteta, pp. 121-131, Ljubljana.

Day, M.J., 2007a: Natural and anthropogenic hazards in the karst of Jamaica.- In: Parise, M. \& J. Gunn (eds.) Natural and Anthropogenic Hazards in Karst Areas: Recognition, Analysis and Mitigation. The Geological Society, London, Special Publication 279, pp.173-184, London.

Day, M.J., 2007b: The karstlands of Antigua, their landuse and conservation.- The Geographical Journal, 173,1 ,

Day, M.J. \& M.S. Chenoweth, 2004a: The karstlands of Trinidad and Tobago, their land use and conservation.- The Geographical Journal, 170, 3, 256-266.

Day, M.J. \& M.S. Chenoweth, 2004b: Cockpit Country cone karst, Jamaica.- In: Gunn, J. (ed.) The Encyclopedia of Caves and Karst Science. Taylor and Francis, pp. 233-235, New York.

Day, M.J. \& S. Koenig, 2002: Cave monitoring priorities in Central America and the Caribbean.- Acta Carsologica, 30, 1, 123-134.

Day, M.J. \& J.A. Kueny, 2004: Military uses of caves.- In: Gunn, J.(ed.) The Encyclopedia of Caves and Karst Science. Taylor and Francis, pp. 513-515, New York.

Donoghue, E., 2002: Black Women White Men: The Sexual Exploitation of Female Slaves in the Danish West Indies.- Africa World Press, pp. 191, Trenton, New Jersey.

Duval, D.T., 2004: Tourism in the Caribbean: Trends, Developments, Prospects.- Routledge, pp.302, London.

Eyre, L.A., 1980: The Maroon Wars in Jamaica: A geographical appraisal.- The Jamaica Historical Review, 12, 80-102.

Fermor, J., 1972: The dry valleys of Barbados: a critical review of their pattern and origin.- Transactions of the Institute of British Geographers, 57, 153 - 165. 
Ford, D.C. and P.W. Williams, 2007: Karst Hydrogeology and Geomorphology. John Wiley, pp. 562, Chichester.

Handler, J.S., 2003: Escaping slavery in Barbados.- Presented at Collective Degradation: Slavery and the Construction of Race. November 7-8, 2003 Gilder Lehrman Center for the Study of Slavery, Resistance and Abolition, Yale University.

Harris D.R., 1965: Plants, animals and Man in the outer Leeward Islands, West Indies.- University of California Press, pp.184, Berkeley.

Intergovernmental Panel on Climate Change (IPCC), 2007: Climate Change 2007. UNEP, 23pp, Geneva.

Kueny, J.A. \& M.J. Day, 1998: An assessment of protected karst landscapes in the Caribbean.- Caribbean Geography, 9, 2, 87-100.

Lashley, B. \& S.B. Bandara, 2001: A Bibliography of Natural Hazards in the Caribbean. Caribbean Disaster Information Network, pp.304, Kingston, Jamaica.

Lasserre, G., 1954: Notes sur la karst de la Guadeloupe.Erdkunde, 8, 115-118.

Monroe, W.H., 1976: The Karst Landforms of Puerto Rico.- USGS Professional Paper, 899, Government Printing Office, pp.69, Washington.

Mujica-Ortiz, B. \& M.J. Day, 2001: Karst conservation and protected areas in northern Puerto Rico.- Caribbean Geography, 12, 1, 11-23.

Lehmann, H., 1954: Der tropische Kegelkarst auf den grossen Antillen.- Erdkunde 8, 130-139.

Nunez Jimenez, A., 1984: Cuevas y Carsos.- Editoria Cientifico-Tecnica, pp.431, Havana.

Mylroie, J.E., 2004: Speleogenesis: coastal and oceanic settings.- In: Gunn, J., (ed.) Encyclopedia of Caves and Karst Science. Fitzroy Dearborn, pp. 674-677, London.

Mylroie, J.E. \& J.L. Carew, 1990: The flank margin model for dissolution cave development in carbonate platforms.- Earth Surface Processes and Landforms, 15, 413-424.

Mylroie, J.E. \& J.L. Carew, 1995: Karst development on carbonate islands.- In: Budd, D.A., Harris, P.M. \& A. Saller, (eds) Unconformities and Porosity in Carbonate Strata. American Association of Petroleum Geologists Memoir 63, pp. 55-76, Tulsa, Oklahoma.

Mylroie, J.E. \& J.L. Carew, 2000: Speleogenesis in coastal and oceanic settings. In: Klimchouk, A.B., Ford, D.C., Palmer, A.N. \& W. Dreybrodt (eds.) Speleogenesis: Evolution of Karst Aquifers.- National Speleological Society, pp. 226-233, Huntsville, Alabama.
O’Hara, M., 1990: Flood hydrology of western Jamaica: A study in a karstic limestone Environment.- Singapore Journal of Tropical Geography, 11, 2, 100-116.

Panos, V. \& O. Stelcl, 1968: Physiographic and geologic control in development of Cuban Mogotes.Zeitschrift fur Geomorphologie, 12, 2, 117-173.

Pattulo, P., 1996: Last Resorts: The Cost of Tourism in the Caribbean. Cassel, pp.220, New York.

Rouse, I. 1992: The Tainos: Rise and Decline of the People Who Greeted Columbus.- Yale University Press, pp.211, New Haven, Connecticut.

Simms, A. \& H. Reid, 2006: Up in Smoke? Latin America and the Caribbean: the Threat from Climate Change to the Environment and Human Development.New Economic Foundation, pp.44, New York.

Steadman D.W., Pregill, G.K. \& S.L. Olson, 1984: Fossil Vertebrates from Antigua, Lesser Antilles: Evidence for Late Holocene Human-Caused Extinctions in the West Indies.- Proceedings of the National Academy of Sciences 81, 14, 4448-4451

Sweeting, M.M. 1958: The karstlands of Jamaica.- The Geographical Journal, 124, 2, 184-199.

Tarhule-Lips, R., 2004: Caribbean Islands. In: Gunn, J., (ed.) Encyclopedia of Caves and Karst Science. Fitzroy Dearborn, pp.189-190, London.

Thompson, A.O., 2002: In the Shadow of the Plantation: Caribbean History and Legacy.- Ian Randle Publishers, pp.504, Kingston, Jamaica.

Thompson, A.O., 2006: Flight to Freedom: African Runaways and Maroons in the Americas.- University of the West Indies Press, pp.381, Kingston, Jamaica.

UNEP, 2005: Caribbean Environment Outlook.- UNEP, pp.114, Nairobi, Kenya.

USGS, 2006: Minerals Yearbook.- [Online] Available from: http://minerals.usgs.gov/minerals/ pubs/myb. html [Accessed 3 July 2007].

Urich, P.B. \& M.J. Day, 2005: Potential impacts of sealevel rise on Belize.- Caribbean Geography, 14, 2 ,

Waltham, T., Bell, F. \& M. Culshaw, 2005: Sinkholes and Subsidence: Karst and Cavernous Rocks in Engineering and Construction.- Springer-Verlag, pp.382, Berlin.

Watts, D., 1987: The West Indies: Patterns of Development, Culture and Environmental Change Since 1492.- Cambridge University Press, pp.609, Cambridge.

Wilson, S.M., 2007: The Archaeology of the Caribbean.Cambridge University Press, pp.209, Cambridge.

Yuan, D., 1997: Rock desertification in the subtropical karst of South China.- Zeitschrift für Geomorphologie, Supplementbände, 108, 81-90. 